\title{
Alteration of macroinvertebrate community in tropical aquatic systems in relation to sediment redox potential and overlaying water quality
}

\author{
${ }^{* 1}$ D. Chakrabarty and ${ }^{2}$ S. K. Das \\ ${ }^{1}$ Department of Zoology, Krishnagar Govt. College, Krishnagar, Nadia, India \\ ${ }^{2}$ Department of Environmental Science, Netaji Subhas Open University, Wood Burn Park, Kolkata-700020, India \\ Received 23 September 2005; $\quad$ revised 11 November 2005; $\quad$ accepted 27 November $2005 \quad$ available online 22September 2005
}

\begin{abstract}
Limnological studies in two tropical Indian aquatic habitats showed that macroinvertebrate communities have greater diversity than other biotic communities present there. Sediment redox potential is found to be an important factor for alteration of macroinvertebrate communities in aquatic bodies. Anthropogenic activities have influenced the changing of sediment redox potential values of the studied sites and there by affected the macroinvertebrate communities.
\end{abstract}

Key words: Macroinvertebrate, redox potential, mergelef index, shannon-weiner diversity index, lentic, lotic

*Corresponding Author, E-mail: das sanjibm@yahoo.com

\section{INTRODUCTION}

Fresh water is an important driving force, cycling minerals and nutrients around the terrestrial environment and has been defined as those systems comprising human communities, socioeconomic interactions, and biophysical processes co-occurring in space and time. Evaluation of the biological community of a water body provides a sensitive and cost effective means of assessing stream condition. Aquatic ecosystems both lentic and lotic are characterized by great variability and complexibility which is getting compounded by increasing anthropogenic activity. Yet as a habitat fresh water is of great biological interest because the habitats concern are highly variable encompassing a great range of types and chemical variability more so than any other type of habitat, so that no two fresh water bodies are ever quite the same (Willmer, 2000). It have been compared two kinds of aquatic habitats (one lentic and one lotic). All the two sites investigated are situated near the trophic of cancer (situated at longitude $88^{\circ} 33^{\prime}$ E, latitude $23^{\circ} 24^{\prime} \mathrm{N}$, of West Bengal, an eastern province of India). The lentic aquatic system is heavily affected by anthropogenic activity and the lotic system was not so heavily affected. The various Physico-chemical properties of water, sediment and different macroin vertebrate communities of those systems has been studied. Macroinvertebrate communities tend to have greater diversity than fish or other biotic communities in the same stream or lake, which makes evaluation with some community diversity metrics more meaningful. Macroinvertebrates are fairly stationary, easy to collect, and are responsive to human disturbance. In addition, the relative sensitivity or tolerance of many macroinvertebrates is well known. In general they provide a simple hands-on approach to understanding and measuring stream health. In order to adequately evaluate the overall ecological integrity of aquatic systems it is necessary to develop a monitoring program that encompasses chemical, physical, and biological integrity (EPA, 1990). Recent researches also shown that chemical properties like specific conductance, $\mathrm{pH}$ and sulphate content etc. controls the availability and propagation of macroinvertebrate in an aquatic system (Dallas, 1999) but the information regarding the relation between redox potential, and macroinvertibrate population is not available. it has been tried to find whether there is any relation between macroinvertebrate community and sediment redox potential is there, because sediment redox potential of any aquatic body plays important role in nutrient influx. The lentic system is an ox-bow lake (Hansadanga Beel), which is highly polluted due to anthropogenic activities, and the other one system is less polluted river (River Jalangi) and from this tried to assess the alteration of macroinvertebrates in these fresh water ecosystems. 


\section{MATERIALS AND METHODS}

An approximate stretch of $10 \mathrm{~km}$ of both the aquatic systems had been selected for sampling. Ten sampling sites approximately $4 \mathrm{~km}$. apart were selected at upstream, middle and down stream of the river as, each zone consisted of three sampling sites, near by two opposite banks and in mid stream and has been demarcated as East (E), besides township, Middle (M) and West (W) opposite to town ship. Results are expressed as mean of the three points. Similarly ten points were selected in case of Hansadanga Beel (HB) $200 \mathrm{~m}$ apart.

Water, sediment as well as biological samples were collected fortnightly from all the ten sites located along the river Jalangi (R-J) and the Ox-bow lake, Hansadanga Beel (H-B) for physico-chemical and bacteriological analysis. Sampling was done between 9 a.m. to 11 a.m. from both sites at a depth of $5 \mathrm{~cm}$ from the surface. Water samples were collected in plastic containers (volume approx. 2 lit.). Temperature and $\mathrm{pH}$ were measured immediately after the collection of the sample. Physico-chemical analysis for conductivity, dissolved oxygen (D.O.), ammoniacal nitrogen, oil and grease were performed in the laboratory on same day or within a week. Analyses of all parameters were done following the standard methods as out lined (Anonymous 1992). Water Quality Index (WQI) (Table 1) values were calculated Ott (1978), Harkins (1974) on the basis of weighting and rating of the chemical parameter as follows:

WQI $(Q)=\sum_{i=1}^{i=n} w_{i} q_{i}$

Where $\mathrm{w}_{\mathrm{i}}$ and $\mathrm{q}_{\mathrm{i}}$ are the unit weight and the quality rating of the $i^{\text {th }}$ parameter respectively. WQI for various water bodies were calculated as follows.

The weighting $\left(\mathrm{w}_{\mathrm{i}}\right)$ for various water quality parameters are assumed to be inversely proportional to the recommended standard. The proportionality constant:

$$
\begin{aligned}
& \mathrm{K}=1 / \sum_{\mathrm{i}=1}^{\mathrm{i}=\mathrm{n}} 1 / \mathrm{v}_{\mathrm{i},} \\
& \mathrm{q}_{\mathrm{i}}=100 \times\left(\mathrm{v}_{\mathrm{i}} / \mathrm{s}_{\mathrm{i}}\right)
\end{aligned}
$$

Where $v_{i}$ is the measured value of the $i^{\text {th }}$ parameter and $s_{i}$ is the standard of permissible value. This equation ensures that $\mathrm{q}_{\mathrm{i}}=0$ when a pollutant is totally absent in water and $q_{i}=100$ when the value of this parameter is just equal to It's permissible value. Thus the higher the value of $q_{i}$ the more polluted is the water. However, $\mathrm{q}_{\mathrm{p}}{ }^{\mathrm{H}}$ and $\mathrm{q}_{\mathrm{D} \text {.o. }}$. were calculated on the basis of $\mathrm{q}_{\mathrm{p}}{ }^{\mathrm{H}}=100 \times(\mathrm{vpH}-7.00) /(8.50-7.00)$ considering the ideal value of $\mathrm{pH}$ is 7.00 and $\mathrm{q}_{\text {D.O. }}=100 \times\left(14.60-\mathrm{v}_{\text {D.O. }}\right)$ / (14.60- 3.00) as the ideal value of D.O. is $14.60 \mathrm{mg} / \mathrm{l}$ (the solubility of pure $\mathrm{O}_{2}$ in pure water at $0^{\circ} \mathrm{C}$ ) and 3.00 $\mathrm{mg} / \mathrm{l}$ is the minimum standard value (Anonymous, 1992). Water Quality Index (WQI) values, a subjective indices, to represent the actual condition of water quality, has been computed considering the level of $\mathrm{pH}$, conductivity, dissolved oxygen (D.O.), ammoniacal nitrogen, oil and grease. WQI values could be classified as $<50=$ Excellent; $51-80=$ Good; $81-110=$ Fair; 111 -140=Poor; > 140=Unacceptable.

Three sampling sites were earmarked for collection of monthly water samples during the period June 2000 to May 2001. Samples for Physico-chemical and biological analyses were collected from three site every fortnightly. Monthly values were presented as an average of fortnightly collected samples. The sediment samples were collected, air dried, powdered, sieved and then analysed for their chemical properties using the methods described by Jackson (1967) and the redox potential was directly measured using a portable oxidation- reduction potentio meter.

The $\mathrm{pH}$ value, Total $\mathrm{P}$ and Total $\mathrm{N}$ was analysed from the sediment samples following. For bacteriological analysis of the lotic and lentic systems, water of the samples was collected in sterilized capped tubes from ten different spots in each case. Total bacteria was counted using SPC (Standard Plate Count) method. All the methods are described (Anonymous 1992).

Macroinvertebrates were collected from randomly scattered plots, across the river, and also from the lakes (total 10 spots in each study) using hand nets for floating insects and mud samples collected by Ekmans dredge from $1 \mathrm{~m}^{2}$ area and the mud samples was sieved through a plastic net. All the mollusks, larva etc. were collected carefully from the net and floating insects were collected using plankton net.

\section{Community analysis}

To understand a particular biotic community it is very important to work out certain indices. In this case Mergelef index and Shannon-Weiner diversity index were estimated for the purpose of community analysis of the macroinvertebrates. 


\section{Mergelef index}

One of the major component or species diversity is called "species richness" or variety component or Mergelef diversity index (d) and is expressed by simple ratio between total species (S) and total number or importance value (N), Mergelef (1958):

$$
\mathrm{d}=\frac{\mathrm{S}-1}{\log \mathrm{N}}
$$

This index commonly varies between 1 and 5, larger the index value a more healthy body of water. When it tends to 1 pollution is thought to increase and damage is suspected.

\section{Shannon-Weiner diversity index}

In estimating species diversity the most widely used index is the Shannon-Weiner (1949) diversity index. This index designated as $H$ or $H$ which is by definition,

$$
H \text { or } H=-\left(n_{i} / N\right) \log _{e}\left(n_{i} / N\right)
$$

Where $H$ = Shannon-Weiner diversity index

$$
\mathrm{n}_{\mathrm{i}}=\text { importance value of each species }
$$$$
\mathrm{N}=\text { total of importance values. }
$$

The values of this index can theoretically range from 0 to infinity. However, values normally range from 0-4. (Wilhm and Dorris, 1968). After examining diversity in a range of polluted and unpolluted streams concluded that the values of $H$ greater than 3 indicated clean water, values in the range of 1-3 were characterized by moderate pollution and values less than 1 characterized heavily polluted condition.

So, it was tried to describe the extent of pollution in these aquatic systems correlating Mergelef index, Shannon diversity index and WQI (Water Quality Index) value or redox potential of sediment.

The value of Mergelef index and Shannon diversity index of a particular month is divided by the value obtained from $\log _{\mathrm{e}}$ of WQI value of that month in the following way:

(I) $\frac{\text { Mergelef index }}{\log _{\mathrm{e}} \mathrm{WQI}}=\mathrm{M}-\mathrm{Q}$ index

(II) $\frac{\text { Shannon diversity index }}{\log _{\mathrm{e}} \text { WQI }}=\mathrm{S}-\mathrm{Q}$ index
The result is described as (I) M-Q index and (II) S-Q (Table 4) index. The values ranged from 0 to 1 in each case. Again, the value of Mergelef index and Shannon diversity index and of a particular month was divided by the value obtained from $\log _{e}$ of redox potential value of that month the following way:-

(III) $\frac{\text { Mergelef index }}{\log _{\mathrm{e}} \text { redox potential }}=$ M-R index

(IV) $\frac{\text { Shannon diversity index }}{\log _{\mathrm{e}} \text { redox potential }}=$ S-R index

The result is described as (III) M-R index and (IV) S$\mathrm{R}$ index. The values ranged from 0 to 1 in each case.

The result M-Q index, S-Q index, M-R index and S$\mathrm{R}$ index ranged from 0 to 1 in all cases. In every analysis we found that the all values decreases towards zero (0) as the level of pollution increases and a few pollution tolerant species become more abundant and sensitive species decline in abundance whereas values nearer to one $(\sim 1)$ depict good state of an aquatic body.

\section{RESULTS}

The Water Quality Index (WQI) of the overlying (Table 1) water showed either "Excellent" or "Good" state in case of R-J and either "Good" or "Fair" state in case of H-B. However both the aquatic habitat never reached “poor” or "unacceptable” state anytime during the study period in terms of water quality (Table 1). But the values of (WQI) indicated a moderate level of pollution $(<80)$ in almost 10 months of a 12 months study period in $\mathrm{H}-\mathrm{B}$. However, lower values (ed59 and 1.6 times lower in average than $\mathrm{H}-\mathrm{B}$ ) throughout the year showed a very good condition of water quality in case of R-J and remained almost in "Excellent" state throughout the year. The data regarding sediment (Table 2) depict that the variation of $\mathrm{pH}$ between the two aquatic environments in a minor scale but the values of $\mathrm{p}^{\mathrm{H}}$ always remained high in case of R-J. The $\mathrm{P} / \mathrm{N}$ ratio showed two different trends between the two studied sites. In case of R-J the ratio remained always above 1 but in case of $\mathrm{H}-\mathrm{B}$ the values showed lower trend during months of February to September. The values showed similar trend with Shannon-Weiner diversity index. The redox potential of the sediment remained always below $200 \mathrm{mv}$ in $\mathrm{H}-\mathrm{B}$ and showed a condition favorable for eutrophication (Holtan et al., 
1988) throughout the year and for R-J it remained above $200 \mathrm{mv}$ showing a healthy state for aquatic habitat. The values showed almost a similar trend with Mergelef index (Table 3). In the present study Mergelef index of $\mathrm{H}-\mathrm{B}$ varied from 1.48 to 2.15 , and R-J varied from 1.99 to 3.81 (Table 3). Moderately high values reflect the suitability of that habitat for the macroinvertibrates and a relatively stable community in case of R-J compared to H-B throughout the year (Table 7).
The value of $H$ was found to lie between 0.925 and 1.551 in (H-B) and (R-J) lie between 1.010 and 2.186 (Table 3). According to the above relationship it can be said that the $(\mathrm{H}-\mathrm{B})$ is at an immediate state of environmental stress, being more or less in a stable condition and (R-J) showed a good condition for macroinvertibrate community.

Table 1: Water quality index (WQI) value in different stations of the lotic and lentic systems investigated

\begin{tabular}{|lcc|}
\hline \multirow{2}{*}{ Months in 2004 } & $\begin{array}{c}\text { Fish, wild life and non- } \\
\text { contact reaction } \\
\text { (H-B) }\end{array}$ & $\begin{array}{c}\text { Fish, wild life and non- } \\
\text { contact reaction } \\
\text { (R-J) }\end{array}$ \\
\cline { 2 - 3 } January & WQI Value & WQI Value \\
February & 81 & 40 \\
March & 87 & 40 \\
\hline April & 86 & 50 \\
May & 80 & 51 \\
June & 85 & 53 \\
\hline July & 87 & 59 \\
August & 83 & 57 \\
September & 83 & 50 \\
\hdashline October & 88 & 52 \\
November & 90 & 59 \\
December & 74 & 51 \\
\hline
\end{tabular}

Table 2: Data of sediment analysis

\begin{tabular}{|lllllll|}
\hline Months in 2004 & \multicolumn{2}{c}{$\mathrm{pH}$} & \multicolumn{2}{c}{ Total P/N ratio } & \multicolumn{2}{c|}{ Redox potential (mv) } \\
\hline & $(\mathrm{H}-\mathrm{B})$ & $(\mathrm{R}-\mathrm{J})$ & $(\mathrm{H}-\mathrm{B})$ & $(\mathrm{R}-\mathrm{J})$ & $(\mathrm{H}-\mathrm{B})$ & $(\mathrm{R}-\mathrm{J})$ \\
January & 7.56 & 7.89 & 1.164 & 1.775 & 110 & 224 \\
February & 7.77 & 7.65 & 0.987 & 1.750 & 106 & 220 \\
March & 7.80 & 7.73 & 0.933 & 1.520 & 105 & 280 \\
\hline April & 7.52 & 7.78 & 0.874 & 1.377 & 137 & 286 \\
May & 7.35 & 7.98 & 0.808 & 1.425 & 130 & 297 \\
June & 7.19 & 7.59 & 0.979 & 1.550 & 190 & 331 \\
\hline July & 7.22 & 8.26 & 0.912 & 1.208 & 181 & 320 \\
August & 7.19 & 7.98 & 0.927 & 1.350 & 192 & 280 \\
September & 7.14 & 7.53 & 0.948 & 1.298 & 194 & 292 \\
\hline October & 7.10 & 7.04 & 1.179 & 1.037 & 109 & 331 \\
November & 7.27 & 7.64 & 1.144 & 1.129 & 90 & 286 \\
December & 7.33 & 7.72 & 1.152 & 1.397 & 100 & 258 \\
\hline
\end{tabular}


Alteration of macroinvertebrate...

Table 3: Mergelef index and shannon-weiner diversity index of macroinvertebrate for the aquatic system studied

\begin{tabular}{|llccc|}
\hline \multirow{2}{*}{ Months in 2004 } & \multicolumn{2}{c|}{ Mergelef index } & \multicolumn{2}{c|}{ Shannon-weiner diversity index } \\
\hline & (H-B) & (R-J) & (H-B) & (R-J) \\
January & 1.52 & 1.99 & 1.153 & 1.010 \\
February & 1.48 & 2.02 & 1.022 & 1.260 \\
March & 1.52 & 2.54 & 0.925 & 1.449 \\
\hline April & 1.87 & 3.81 & 1.117 & 2.186 \\
May & 1.79 & 3.37 & 1.479 & 2.035 \\
June & 2.12 & 3.70 & 1.403 & 2.024 \\
\hline July & 2.07 & 3.28 & 1.465 & 2.019 \\
August & 2.15 & 3.22 & 1.531 & 2.026 \\
September & 2.15 & 3.16 & 1.551 & 2.027 \\
\hline October & 1.79 & 2.22 & 1.344 & 1.723 \\
November & 1.75 & 2.28 & 1.333 & 1.502 \\
December & 1.58 & 2.10 & 0.943 & 1.302 \\
\hline
\end{tabular}

Table 4: M-Q Index and S-Q index of macroinvertebrate for the aquatic system studied

\begin{tabular}{|c|c|c|c|c|}
\hline \multirow[t]{2}{*}{ Months in 2004} & \multicolumn{2}{|c|}{ M-Q index } & \multicolumn{2}{|c|}{ S-Q index } \\
\hline & (H-B) & (R-J) & $(\mathrm{H}-\mathrm{B})$ & (R-J) \\
\hline January & 0.346 & 0.540 & 0.226 & 0.274 \\
\hline February & 0.331 & 0.548 & 0.229 & 0.342 \\
\hline March & 0.341 & 0.649 & 0.207 & 0.370 \\
\hline April & 0.426 & 0.969 & 0.255 & 0.556 \\
\hline May & 0.403 & 0.848 & 0.333 & 0.512 \\
\hline June & 0.475 & 0.909 & 0.314 & 0.497 \\
\hline July & 0.469 & 0.811 & 0.332 & 0.499 \\
\hline August & 0.487 & 0.823 & 0.347 & 0.518 \\
\hline September & 0.480 & 0.800 & 0.346 & 0.513 \\
\hline October & 0.398 & 0.545 & 0.299 & 0.423 \\
\hline November & 0.406 & 0.580 & 0.310 & 0.382 \\
\hline December & 0.359 & 0.554 & 0.214 & 0.341 \\
\hline
\end{tabular}

Table 5: M-R Index and S-R index of macroinvertebrate for the aquatic system studied

\begin{tabular}{|lcrrr|}
\hline \multicolumn{2}{|c}{ Months in 2004 } & \multicolumn{2}{c}{ M-R index } & \multicolumn{2}{c|}{ S-R index } \\
\hline & $(\mathrm{H}-\mathrm{B})$ & $(\mathrm{R}-\mathrm{J})$ & $(\mathrm{H}-\mathrm{B})$ & $(\mathrm{R}-\mathrm{J})$ \\
January & 0.3234 & 0.3678 & 0.2453 & 0.1866 \\
February & 0.3175 & 0.3747 & 0.2193 & 0.2337 \\
March & 0.3268 & 0.4511 & 0.1989 & 0.2573 \\
\hline April & 0.3808 & 0.6743 & 0.2274 & 0.3869 \\
May & 0.3683 & 0.5922 & 0.3043 & 0.3576 \\
June & 0.4045 & 0.6379 & 0.2677 & 0.3489 \\
\hline July & 0.3988 & 0.5694 & 0.2822 & 0.3505 \\
August & 0.4095 & 0.5719 & 0.2916 & 0.3598 \\
September & 0.4087 & 0.5573 & 0.2948 & 0.3574 \\
\hline October & 0.3816 & 0.3827 & 0.2865 & 0.2970 \\
November & 0.3897 & 0.4035 & 0.2968 & 0.2658 \\
December & 0.3434 & 0.3819 & 0.2050 & 0.2351 \\
\hline
\end{tabular}


Table 6: Data regarding the bacteriological investigation of the two aquatic system study

\begin{tabular}{|lcc|}
\hline Months in 2004 & \multicolumn{2}{c|}{ Total coliform (MPN/dl) } \\
\hline & $(\mathrm{H}-\mathrm{B})$ & $(\mathrm{R}-\mathrm{J})$ \\
January & $0.73 \times 10$ & $0.39 \times 10^{4}$ \\
February & $1.18 \times 10^{4}$ & $0.37 \times 10^{4}$ \\
March & $1.35 \times 10^{4}$ & $0.41 \times 10^{4}$ \\
\hline April & $2.03 \times 10^{4}$ & $0.55 \times 10^{4}$ \\
May & $2.12 \times 10^{4}$ & $0.87 \times 10^{4}$ \\
June & $3.45 \times 10^{4}$ & $1.00 \times 10^{4}$ \\
\hline July & $3.08 \times 10^{4}$ & $0.90 \times 10^{4}$ \\
August & $2.82 \times 10^{4}$ & $0.82 \times 10^{4}$ \\
September & $2.66 \times 10^{4}$ & $0.71 \times 10^{4}$ \\
\hline October & $2.38 \times 10^{4}$ & $0.63 \times 10^{4}$ \\
November & $1.65 \times 10^{4}$ & $0.68 \times 10^{4}$ \\
December & $1.79 \times 10^{4}$ & $0.70 \times 10^{4}$ \\
\hline
\end{tabular}

Table 7: Monthwise percentage of population in different groups of macroinvertebrates in the studied sites

\begin{tabular}{|c|c|c|c|c|c|c|c|c|c|c|c|c|}
\hline & \multicolumn{2}{|c|}{ Oligocheate } & \multicolumn{2}{|c|}{ Coleoptera } & \multicolumn{2}{|c|}{ Diptera } & \multicolumn{2}{|c|}{ Hemiptera } & \multicolumn{2}{|c|}{ Gastropoda } & \multicolumn{2}{|c|}{ Bivalvia } \\
\hline & (H-B) & (R-J) & (H-B) & (R-J) & (H-B) & (R-J) & (H-B) & (R-J) & (H-B) & (R-J) & (H-B) & (R-J) \\
\hline Jan & 7.80 & 0 & 0 & & 18.85 & 3.36 & 0 & 0 & 73.35 & 93.20 & 0 & 3.45 \\
\hline Feb & 3.96 & 0 & 0 & 0 & 28.44 & 14.07 & 0 & 0 & 67.60 & 79.77 & 0 & 6.16 \\
\hline Mar & 2.47 & 0 & 0 & 1.93 & 25.66 & 7.92 & 0 & 0 & 71.87 & 79.94 & 0 & 10.21 \\
\hline Apr & 4.14 & 0 & 0 & 4.64 & 20.31 & 22.16 & 3.00 & 2.96 & 72.54 & 63.92 & 0 & 6.31 \\
\hline May & 5.30 & 0 & 0 & 0 & 19.26 & 13.18 & 14.93 & 2.25 & 60.51 & 71.17 & 0 & 13.40 \\
\hline Jun & 4.55 & 0 & 0 & 1.89 & 20.23 & 13.24 & 7.77 & 2.42 & 67.45 & 75.84 & 0 & 6.62 \\
\hline Jul- & 2.94 & 0 & 0 & 0 & 18.51 & 15.52 & 6.26 & 2.94 & 72.29 & 75.65 & 0 & 5.89 \\
\hline Aug & 5.26 & 0 & 0 & 0 & 26.80 & 16.63 & 8.06 & 3.42 & 59.87 & 75.60 & 0 & 4.35 \\
\hline Sep & 6.40 & 0 & 0 & 0 & 30.38 & 17.50 & 6.73 & 3.60 & 56.49 & 75.31 & 0 & 3.60 \\
\hline $\mathrm{Oct}$ & 4.40 & 0 & 0 & 0 & 32.76 & 8.49 & 0 & 0 & 62.81 & 87.54 & 0 & 3.97 \\
\hline Nov & 6.16 & 0 & 0 & 0 & 29.83 & 15.85 & 0 & 0 & 64.00 & 81.96 & 0 & 2.19 \\
\hline Dec & 3.28 & 0 & 0 & 0 & 15.63 & 9.48 & 0 & 0 & 81.09 & 86.08 & 0 & 4.44 \\
\hline
\end{tabular}

\section{DISCUSSION AND CONCLUSION}

Benthic invertebrates help in increased transport of phosphorous by bioturbation and the process is due to gas ebullition, terbulance and advection (Bostrom, et al., 1982). In fresh water sediments, the macro fauna is usually-dominated by a few groups, Oligichaetes, Chironomids, amphipods and bivalves. In addition to above mentioned organisms, the sediment-water interface is also affected by smaller animals, e.g. copepods, ostrapods, nemapods and protozoans. The important effect of the benthic animals is the downward transport of oxygen and other terminal electron acceptors to the sediments (Anderson, et al., 1988). Increased availability of terminal electron acceptor leads to a more efficient sediment mineralization. This means liberation of phosphate. A positive relation between the phospohorous liberation from the sediment cores and the amount of benthic micro fauna has been observed in several investigations (Holdren and Armstrong, 1980; Wisniewski and Planter, 1985; Starkel, 1985; Mitraszewski and Uchmanski, 1989). Mortimer (1942, 1942) very convincingly demonstrated low in oxidized conditions sediments efficiently bound phosphate, while a considerable release of phosphorous occurred when the sediments are reduced. During oxidized conditions phosphate is sorbed to Iron (III) mainly in the from of hydrous Iron 
(III) oxide gels. These aggregates may form in an oxidized surface from overlying waters. In anaerobic situations Iron (III) is reduced to Iron (II) where by both iron and sorbed phosphates are returned to solutions. Dissolved phosphate can then be transported to lake water from sediment pore water or sediment surface. This model originates from the early works of (Einsele, 1936, 1937 and 1938; Einsele and Vetter, 1938; Ohle, 1937 and Mortimer, 1942, 1942). At redox potential below $200 \mathrm{mv}$, part of the Iron (III) pool in surface sediment reduced to Iron (II). Iron (II) and associated phosphorous are thereby returned to solution. So the value of sediment redox potential indicates the general condition of any aquatic body.

It was also studied the redox condition of the sediment of the two aquatic bodies. The general purpose in this study is to find a relation between redox potential of sediment and macroinverterate population as well as alteration between Water Quality Index (WQI) and macroinverterate population. It was found a direct corelation between Mergelef Index and redox potential of sediment and Water Quality Index (WQI) value in both the sets. With increasing Mergelef Index we found a greater value of redox potential almost in every case and from our knowledge we have seen at redox potential below $200 \mathrm{mv}$ part of the Iron (III) pool in surface sediment reduced to Iron (II). Their by release of phosphorous and which leads to eutrophication (Holtan et al., 1988). Extensive study of the faunal components revealed that $(\mathrm{H}-\mathrm{B})$ is fast progressing towards eutrophication which is supported by the presence of indicator species (mainly oligocheates) and such values of different index. Moreover, values of community indices especially Shannon-Weiner diversity index indicated an intermediate scale of pollution in case of (H-B) and a good state in case of (R-J). A distinct trend of variation was found in case of sediment $\mathrm{P} / \mathrm{N}$ ratio, values of redox potential and values of Mergelef and Shannon-Weiner diversity index. The value of MPN for total coliform reflects 3.143 times higher value (Table 6) in average is case of $\mathrm{H}-\mathrm{B}$ than $\mathrm{R}$ $\mathrm{J}$, depicting the eutrophied state in case of the former. In our new index study we found that values nearer to one (1) depict good state of an aquatic body. Where as values nearer to zero (0) indicates pollution. Analyzing the new index (M-R index and S-R index) for both the aquatic bodies, we found a clear difference throughout the year and we experienced a higher level of pollution from other studies and observation in case of $\mathrm{H}$-B than
R-J (Table 6). The M-Q and S-Q index also showed same trend with $\mathrm{M}-\mathrm{R}$ and $\mathrm{S}-\mathrm{R}$ index. It was also also found here a distinct difference between the two aquatic bodies indicating a greater polluted state incase of $\mathrm{H}$ $\mathrm{B}$ than R-J (Table-5). Above mentioned new index (M$\mathrm{R}$ index / S-R index or M-Q index / S-Q index) more reliably depicted the state of condition of the aquatic body than any other index. We experienced such index to be very much fit for lentic or lotic aquatic bodies in regard to study of macroinvertibrates community.

\section{REFERENCES}

Anderson, G., Graneli, W. and Stenson, J., (1988). The influence of animals on phosphorous cycling in lake ecosystems. Hydrobiol., 170, 267-284.

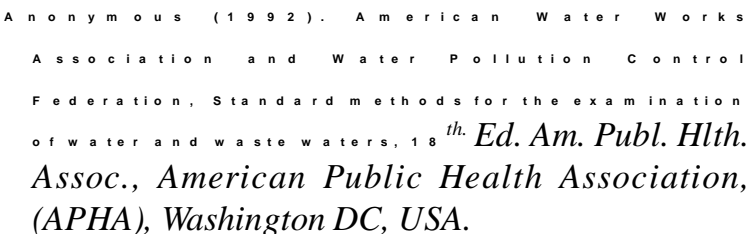

Bostrom, B., Jansson, M. and Forsberg, C., (1982). Phosphorous release from lake sediments. Arch. Hydrobiol. Beih. Ergebn. Limnol., 18, 5-59.

Dallas, H. F., Janssense, M. P. and Day, J. A. (1999). An aquatic macroinvertebrate and chemical database for riverine ecosystems. Water Sa., 25 (1).

Einsele, W., (1936). Uber die Beziehungen des Einsenkreislaufs zum phosphatkreislauf in eutrophen sec., Arch.

Einsele, W., (1937). Physikalische-chemische Betrachtung einiger probleme des limnischen Mangan -und Eisenkreislaufs. Verh. Int. Ver. Limnol., 5, 69-84.

Einsele, W., (1938). Uber Chemischen and kolloidchemische vorgange in Eisen.Phosphatsystemn unter Limnochemischen and Limnogeologischen Gesicht Spunkten. Arch. Hydrobiol., 33, 361-387.

Einsele, W. and Vetter, H., (1938). Untersuchungen uber die Entwicklung der physikalischen und Chemischen verhaltnisseim Jahreszyklus in einem ma Big eutrophen see (Schleinsee bei Langenargen). Int. Rev. Hydrobiol., 36, 285-324. 
EPA., (1990). Biological Criteria: National Program Guidance for Surface Waters, U.A. Environmental Protection Agency, EPA-440/5-90-004.

Harkins, R. D., (1974). An objective water quality index. J. Wat. Pollut. Control. Fed. 46, 588.

Holtan, H., Kamp-Nielsen, L. and Stuanes, A. O., (1988). Phosphorous in soil, water and sediment: an overview. Hydrobio., 170, 19-34.

Holdern, G. C. and Armstrong, D. E., (1980). Factors affecting phosphorous release from intact lake sediment cores. Environ. Sci. Technol., 14, 79-87.

Margalef, R., (1958). Perspective in ecological theory. Univ. Chicago Press, 122, Chicago, USA.

Mitraszewski, P. and Uchmanski, J., (1989). A numerical model of phosphorous exchange between the sediments and the near bottom water in a lake Ekol. Pol., 36 (3-4), 317-346.

Mortimer, C. H., (1942). The exchange of dissolved substances between mud and water in lakes, II. J. Ecol., 30, 147-201.

Mortimer, C. H., (1942). Fertilizers in fish ponds. Her Majesty's stationary office, London, Fisheries Publication, 5, 155.
Ohle, W., (1937). Kolloidgele als Nahrstoffregulanten der Gewasser. Naturwissen Schaften, 25, 471-474.

Ott, W. R., (1978). Environmental indices theory and practices, Ann. Arbor. Aci. Publis, Inc: 202-213.

Starkel, W. M., (1985). Predicting the effects of macrobenthos on the sediment water flux of metals and phosphorous. Can. J. Fish. Aquat. Sci., 42, 95-100.

Shanon, C. E. and Weiner, W., (1949). The Mathematical Theory of Communication. University of Illinois press, 117, Urbana, USA.

Willmer, P., Graham, S. and Jhonston, I., (2000). Environmental physiology of animals. Blackwell Science Ltd.

Wilhm, J. L. and Dorris, T. C., (1968). Biological parameters of water quality criteria. Bioscience, 18, 477-481.

Wisniewski, R. J. and Planter, M., (1985). Exchange of phosphorous across sediment. Water interface (with special attention to the influence of biotic factors) in several lakes of different trophic status. Verh. Int. Ver. Limnol., 22, 3345-3349. 